\title{
Report on the External Quality Assessment Scheme for Metabolite Testing in Korea (2016-2017)
}

\author{
Soo-Youn Lee \\ Department of Laboratory \\ Medicine \& Genetics, \\ Samsung Medical Center, \\ Sungkyunkwan University \\ School of Medicine, Seoul, \\ Korea
}

\section{Corresponding author:}

Soo-Youn Lee

Department of Laboratory

Medicine \& Genetics, Samsung

Medical Center, Sungkyunkwan

University School of Medicine,

81 Irwon-ro, Gangnam-gu, Seoul 06351, Korea

Tel: $+82-2-3410-1834$

Fax: $+82-2-3410-2719$

E-mail: suddenbz@skku.edu

pISSN: 2384-2458

elSSN: 2288-7261

\begin{abstract}
External quality assessment (EQA) trials of conventional newborn screening tests for phenylketonuria, galactosemia, congenital adrenal hyperplasia, maple syrup urine disease, homocystinuria, and congenital hypothyroidism, as well as extended newborn screening tests using tandem mass spectrometry, were performed twice in 2016 and 2017. A total of 44 specimens in the form of dried blood spots were distributed in each trial to 16 laboratories. The response rate of these laboratories was $100 \%$. The mean, standard deviation, coefficient of variation, median, and cut-offs were evaluated for each analyte in the newborn screening tests. EQA trials for the analyses of methylmalonic acid, vanillylmandelic acid, catecholamines, metanephrines, organic acids, and amino acids were also performed. A well-designed EQA program and continuous education would improve the performance of metabolite testing.
\end{abstract}

(J Lab Med Qual Assur 2018;40:136-148)

Key Words: External quality assessment, Newborn screening, Tandem mass spectrometry, Amino acid, Organic acid, Metabolite
서론

대한임상검사정도관리협회에서는 1997년도부터 선천성 대사질환 선별검사에 대한 신빙도조사사업을 시작하여 매 년 2회의 신빙도조사를 시행해오고 있다. 탠덤질량분석기 (tandem mass spectrometry, MS/MS)를 이용한 광범위선 별검사에 대한 신빙도조사사업은 2004년도에 예비 신빙도조 사를 실시한 이래 2007년도부터 정규항목으로 포함하여 시 행 중이다[1]. 2011년도부터는 예비 신빙도조사를 거쳐 소 변 메틸말론산(methylmalonic acid, MMA)와 바닐만델산 (vanillylmandelic acid, VMA), 소변 유기산 분석을 추가하였 고, 2012년도부터는 혈장 아미노산 및 유기산 종목을 추가하 였으며, 2014년도에는 요중 카테콜라민(catecholamines), 메 타네프린(metanephrines) 종목을, 2016년도부터는 혈중 카 테콜라민 및 메타네프린 종목까지 추가하면서 점차 사업대상 종목을 확대해 시행하였다[2-6]. 이에 상기 검사항목들에 대 해 2016년 및 2017년 실시된 총 4회의 신빙도조사결과를 분석
요약하여 보고하고자 한다.

\section{재료 및 방법}

\section{1. 대상 및 검체}

2016년도 및 2017년도 총 4회의 대사물질검사 신빙도조 사 대상항목 및 정도관리 검체현황은 Table 1에 정리하였다. 정도관리 검체는 모두 자가제조 검체였으며, 성분별 표준물 질 및 상품화된 정도관리물질을 활용하여 준비하였다. 검체 제조에 사용된 표준물질은 Sigma-Aldrich (St. Louis, MO, USA), Toronto Research Chemicals Inc. (North York, ON, Canada), International Laboratory USA (South San Francisco, CA, USA), Crystal Chem USA (Elk Grove Village, IL, USA) 등으로부터 구매하였다. 또한 Bio-Rad Laboratories (Hercules, CA, USA), Simens Healthcare Diagnositcs Inc. (Tarrytown, NY, USA) 등으로부터 구매한 보정물질이나 정도관리물질도 검체 제조에 일부 활용하였다. 
Table 1. Test items and specimens included in the proficiency tests

\begin{tabular}{|c|c|c|c|c|c|c|}
\hline \multirow{3}{*}{ Test items } & \multirow{3}{*}{ Category } & \multirow{3}{*}{ Specimen } & \multicolumn{4}{|c|}{ No. of specimens } \\
\hline & & & \multicolumn{2}{|c|}{ Year 2016} & \multicolumn{2}{|c|}{ Year 2017} \\
\hline & & & 1st trial & 2nd trial & 1st trial & 2nd trial \\
\hline \multirow[t]{6}{*}{ Conventional } & Phenylketonuria & DBS & 12 & 12 & 12 & 12 \\
\hline & $\begin{array}{l}\text { Congenital hypothyroidism (thyroid- } \\
\text { stimulating hormone, thyroxine-total or free) }\end{array}$ & & 10 & 10 & 10 & 10 \\
\hline & Galactosemia & & 12 & 12 & 12 & 12 \\
\hline & $\begin{array}{l}\text { Congenital adrenal hyperplasia } \\
\text { (17-hydroxyprogesterone) }\end{array}$ & & 12 & 12 & 12 & 12 \\
\hline & Maple syrup urine disease & & 12 & 12 & 12 & 12 \\
\hline & Homocystinuria & & 12 & 12 & 12 & 12 \\
\hline Methylmalonic acid & & Urine & 3 & 3 & 3 & 3 \\
\hline Organic acids & Approximately 70 organic acids & Urine & 2 & 2 & 2 & 3 \\
\hline Amino acids & Approximately 40 amino acids & Plasma & 2 & 2 & 2 & 2 \\
\hline \multirow[t]{2}{*}{ Catecholamines } & Dopamin, epinephrine, norepinephrine & Urine & 3 & 3 & 3 & 3 \\
\hline & & Plasma & 3 & 3 & 3 & 3 \\
\hline \multirow[t]{2}{*}{ Metanephrines } & Metanephrine, normetanephrine & Urine & 3 & 3 & 3 & 3 \\
\hline & & Plasma & 3 & 3 & 3 & 3 \\
\hline
\end{tabular}

Abbreviation: DBS, dried blood spot.

모든 신빙도조사 회차별로 항목별 정상과 비정상 수치가 모두 포함되도록 하였으며, 일부 검체에 대해서는 특정 대사질환에 특이적인 성분 다수를 동시에 포함시켰다. 대사산물검사를 위 한 검체들은 냉동상태로 운반되었으며, 각 기관에서 검체를 수 령한 즉시 냉동 보관하도록 권고하였다.

기본 선별검사의 대상질환으로는 페닐케톤뇨증(phenylketonuria, PKU), 갈락토오스혈증(galactosemia), 선천성 부신과형성증(congenital adrenal hyperplasia), 단풍당 뇨증(maple syrup urine disease, MSUD), 호모시스틴 뇨증(homocystinuria, $\mathrm{HCY}$ ), 선천성갑상선기능저하증 (congenital hypothyroidism) 등 6가지가 포함되었으며, 총 16 기관을 대상으로 각 회차별 총 22 개, 연도별 총 44 개의 건 조혈액여과지(dried blood spot, DBS) 검체를 발송하였다. $\mathrm{MS} / \mathrm{MS}$ 를 이용한 광범위선별검사항목으로 아실카르니틴 (acylcarnitine, AC) 및 아미노산 14종목과 8종의 상대적 비 율(ratio)이 포함되었다. $\mathrm{DBS}$ 정도관리 검체는 모두 자가제 조하여 준비하였다. $\mathrm{DBS}$ 자가제조를 위해 HIV항체와 B형간 염 항원이 음성인 혼합혈청에 식염수로 세척한 $\mathrm{O}$ 형 적혈구 적
당량을 첨가하여 헤마토크릿을 약 $55 \%$ 가 되도록 맞춘 전혈을 준비한 후 측정대상 성분에 대한 표준품을 목표한 농도로 첨 가하였다. 이를 여과지에 $75 \mu \mathrm{L}$ 씩 분주하여 $\mathrm{DBS}$ 를 만든 다음 실온의 암실에서 충분히 말린 후 보관하였다.

아미노산, 유기산검사를 위한 정도관리 검체는 혼합 혈청 (유기산검사를 위한 소변 검체는 정상 성인의 혼합 소변에 특 정 질환에서 대표적으로 상승하는 성분에 대한 표준물질을 고 농도로 첨가하여 제조하였다. 혈장 아미노산분석을 위해서는 정상 성인의 혼합혈장(pooled plasma)에 특정 질환에서 대 표적으로 상승하는 아미노산 성분에 대한 표준물질(SigmaAldrich, St. Louis, MO, USA)을 첨가한 혈장 검체를 제조하 여 발송하였다. Pooled serum 또는 혼합 소변(pooled urine) 에 상품화된 표준물질을 첨가하여 제조하였다. MMA 및 $\mathrm{VMA}$ 신빙도조사 물질로는 정상 성인의 혼합 소변에 해당 표 준물질을 다양한 농도로 첨가하여 각 회차별로 각각 3개씩 제 조 및 발송하였다. 카테콜라민과 메타네프린 종목 신빙도조사 를 검체들 역시 환자들의 혼합 소변 또는 혈액에 해당 표준물 질을 첨가하여 목표농도로 제조 및 발송하였다. 


\section{Journal of LABORATORY MEDICINE and QUALITY ASSURANCE}

Soo-Youn Lee • Quality Assessment of Metabolite Testing

\section{2. 결과 판정 및 분석}

기본선별검사의 경우에는 각 검사기관이 수행하고 있는 종 목에 대해 검사를 실시하여 결과수치와 함께 정상 및 비정상 여부를 판정하여 회신하도록 하였다. 검사결과로부터 각 검사 기관에서 판독하는 정상 및 비정상 여부의 판정결과에 대해 분 석하였다. $\mathrm{MS} / \mathrm{MS}$ 를 이용한 광범위선별검사의 경우 $\mathrm{AC}$ 및 아미노산 결과수치와 함께 정상 및 비정상 여부 판정, 판정기 준치(cut-off) 등을 회신하도록 하였다. 결과분석 시 수치결과 에 대해서는 해당 검사방법을 이용한 응답기관이 3 개 이상인 경우 중앙값, 최소 및 최대값을 제공하였고, 10 개 이상일 경우 에 평균, 표준편차, 변이계수를 제공하였다. 결과분석은 응답 기관에 대해 판정결과 및 판정일치율과 각 기관에서 사용하고 있는 판정기준치에 대한 평균, 중앙값, 최저값, 최고값에 대해 분석하였고, 각 기관의 검사성적에 대한 비교평가 그래프를 제 공하였다.

유기산 및 아미노산검사는 소수의 기관만 검사를 수행하므 로 측정값을 비교할 수 있도록 각 기관이 보고한 주요 성분에 대한 항목과 측정값을 제공하였으며, 신빙도조사물질 제조 시 의도한 진단명을 정답으로 간주하고 각 기관에서 제출한 최종 진단명에 대하여 정오답 여부를 판정하였다. 기타 정량 결과 값에 대해서도 대부분의 종목이 참여기관 수가 많지 않아 통계 분석이 어려우므로, 해당 기관에서 보고한 결과값을 전체 기 관 결과값의 분포범위상에서 확인할 수 있도록 분포표를 제공 하였다. 수탁기관에 대한 정도관리 인증기준은 참가기관 수 5 개 이상이면서 결과판정 일치율이 $70 \%$ 이상인 기본선별검사 종목을 대상으로, 종목별 보고결과의 정답 일치율 $80 \%$ 이상, 참가한 종목 전체 보고결과의 정답일치율 $90 \%$ 이상인 경우이 다.

\section{결과}

\section{1. 참여기관 및 회신율}

2016년도 및 2017년도 신빙도조사에서의 전체 16 기관의 회 신율은 $100 \%$ 로 각 기관에서 실제로 시행하고 있는 검사들에 대해 모두 신빙도조사에 참가 및 회신하였다. 기본 선별검사 6 항목은 2013년도 이후로 본 신빙도조사에 지속적으로 총 16기 관이 참여해왔으나, 2017년도 2차에는 1 기관이 줄어든 총 15 기관이 참여하였다. $\mathrm{MS} / \mathrm{MS}$ 를 이용한 광범위선별검사항목에 대해서는 예년과 마찬가지로 총 15 기관이 신빙도조사에 참여 하였다. VMA검사는 7기관이 지속적으로 참여하였고, $\mathrm{MMA}$ 검사는 4-5개 기관이 참여하였다. 아미노산검사는 회차별로 5-6기관, 유기산검사는 2-4기관이 참여하였다. 카테콜라민과 메타네프린 종목에 대해서는 각 회차별로 소변과 혈액 검체를 각각 3개씩 발송하였으며, 6-7개 기관이 회신하였다.

\section{2. 검사법 및 장비현황}

6 개 질환에 대한 기본 신생아 선별검사에 이용되는 검사방 법은 Fig. 1과 같았다. 기본선별검사에는 효소비색법, 효소면 역측정법, 형광면역법, $\mathrm{MS} / \mathrm{MS}$ 법 등이 이용되어 왔다. 갈락토 오스혈증, 선천성부신과형성증, 선천성갑상선기능저하증 선 별검사는 모든 참여기관에서 면역분석법으로 검사를 시행하 고 있다. 한편, MSUD, HCY 선별검사의 경우 현재 모든 기관 에서 MS/MS법을 활용하고 있는 것으로 나타났으며, PKU검 사에 대해서는 총 16 기관 중 15 기관에서 $\mathrm{MS} / \mathrm{MS}$ 법을 사용하 여 결과를 보고하였다.

VMA, MMA, 유기산검사에는 액체크로마토그래피(liquid chromatography) 또는 액체크로마토그래피-탠덤질량분석법 (liquid chromatography tandem mass spectrometry), 가 스크로마토그래피-질량분석법(gas chromatography-mass

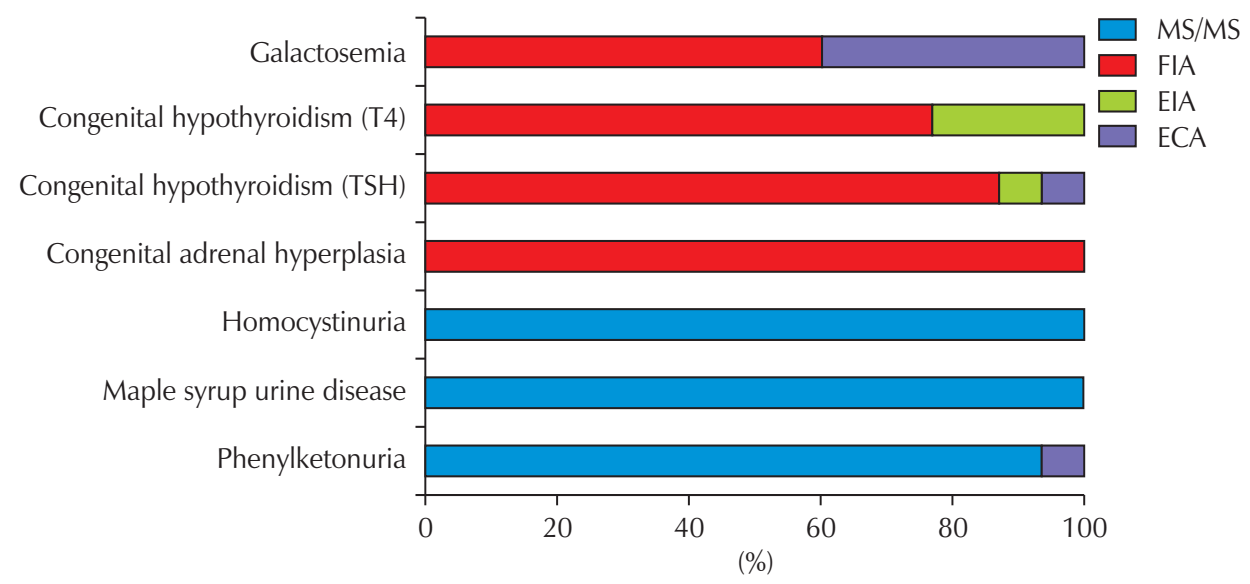

Fig. 1. Analytical methods used for conventional neonatal screening tests of the first trial in 2017. Abbreviations: MS/MS, tandem mass spectrometry; FIA, fluorometric immunoassay using a Perkin-Elmer kit; EIA, enzyme immunoassay; ECA, enzyme colorimetric assay; T4, thyroxine; TSH, thyroid-stimulating hormone. 
spectrometry)이 주로 이용되었으며, 아미노산분석에는 액체 크로마토그래피-탠덤질량분석법 또는 아미노산분석기(amino acid analyzer)가 이용되었다. 요중 및 혈중 카테콜라민과 메 타네프린검사에 있어서는 액체크로마토그래피 또는 액체크로 마토그래피-탠덤질량분석법이 이용되었다.

\section{3. 신빙도조사결과}

6 종 기본 선별검사의 각 항목별 정답률 현황은 Table 2 에 정 리하였다. $\mathrm{MS} / \mathrm{MS}$ 검사상 포함된 각 항목에 대한 판정기준치 의 분포는 Table 3 와 같았으며, 신생아 선별검사에 대해서는 모든 검사항목별로 각 기관들에서 보고한 결과수치와 해당 판 정기준치를 상대적으로 비교 가능하도록 그래프로 제공하였 다. MMA 및 VMA에 대한 신빙도조사 결과는 Table 4, 카테 콜라민과 메타네프린검사 결과는 Table 5 와 Table 6 , 아미노 산분석 결과는 Table 7 , 유기산분석 결과는 Table 8에 제시하 였다.

\section{고찰}

선천성 대사이상질환 조기발견을 위한 신생아선별검사대상 신빙도조사사업은 1997년에 처음 시행되었으며, 2002년도부 터는 매년 2회씩 시행되고 있다. MS/MS를 이용한 광범위선 별검사에 대한 신빙도조사사업은 2007년도부터 시작하였고, 2011년도부터는 아미노산, 유기산, MMA, VMA 등을 포함하 여 종목 확대를 위한 노력이 계속되었다. 2014년도에는 요중 카테콜라민, 메타네프린 종목을, 2016년도부터는 혈중 카테콜 라민 및 메타네프린 종목까지 추가되었다. 정도관리 검체는 상 품화된 정도관리검체와 자가제조 검체를 혼용하여 사용해 왔 는데, 정상과 비정상 수치, 판정기준치 주변 수치가 모두 포함
되도록 하기 위해 자가제조 검체의 비중을 점차 더욱 높이게 되었다.

특히 신생아선별검사의 경우 각 항목별 검체의 수를 증가시 키고 판정기준치보다 경미한 상승수치를 보이는 검체까지도 포함시키므로써 신빙도조사를 통한 각 기관의 검사수행능 및 문제점을 보다 정확히 파악하고 개선하는 데 도움을 주고자 하 였다. 그 결과, 판정의 불일치를 보인 항목들이 일부 항목들 또 는 일부 기관에서 발견되었다. 판정 불일치를 보인 기관들은 판정기준치 주변 수치를 보이는 검체에 대해 판정기준치는 타 기관과 별로 차이가 없으면서 수치결과가 타기관에 비해 차이 를 보이거나, 수치결과는 비슷하지만 해당기관에서 이용 중인 판정기준치가 타기관과 차이가 있어 최종 판정이 달라지는 경 우였다. 기본 신생아 선별검사 종목과 $\mathrm{MS} / \mathrm{MS}$ 를 이용한 광 범위선별검사에 대한 결과판정 시, 결과를 보고한 기관들에서 $80 \%$ 이상의 일치를 보이는 결과를 의도된 정답으로 간주하였 고, 기관 간 일치율이 낮은 경우와 검체 이상이 의심되는 경우 등에 대해서는 판정 보류대상으로 결정하였다.

국가지원대상인 기본 6 종 검사 중 $\mathrm{MS} / \mathrm{MS}$ 로 검사가 가능한 3 가지 항목들에 대해서는 수년 전부터 페닐케톤뇨증검사만을 면역분석법으로 시행하는 1 개 기관을 제외하고는 모두 MS/ $\mathrm{MS}$ 검사법이 활용되고 있으며 검사의 일치율이 높았다. T4나 $\mathrm{TSH}$ 항목의 경우에는 다양한 종류의 정도관리물질 확보가 힘 들며 기관별 검사방법이 달라 항상 어려움을 겪는데, 특히 판 정기준치에 인접한 측정값을 나타내는 항목들은 결과판정 일 치율이 낮아 판정 보류로 결정한 항목들이 있었다. 이러한 검 체들에 대한 분석결과들에 대해서는 기관별 측정값, 측정방법, 판정기준치의 차이와 그에 따른 판정결과의 차이, 재검률에 대 해 각 기관 자체적으로 면밀한 고찰이 필요하겠다. 특히 대부 분의 기관에서 선별검사 양성으로 보고한 비정상 검체에 대해

Table 2. Results of the proficiency testing of conventional neonatal screening tests in 2016

\begin{tabular}{|c|c|c|c|c|}
\hline \multirow{2}{*}{ Variable } & \multicolumn{2}{|r|}{ 1st trial } & \multicolumn{2}{|r|}{ 2nd trial } \\
\hline & No. of institutions & Proportion of correct answers (\%) & No. of institutions & Proportion of correct answers (\%) \\
\hline Phenylketonuria & 16 & 191/192 (99) & 16 & $192 / 192(100)$ \\
\hline Galactosemia & 15 & $178 / 180(99)$ & 15 & $165 / 165(100)$ \\
\hline Congenital adrenal hyperplasia & 14 & $168 / 168(100)$ & 14 & $168 / 168(100)$ \\
\hline Maple syrup urine disease & 15 & $179 / 180(99)$ & 15 & $180 / 180(100)$ \\
\hline Homocystinuria & 15 & $180 / 180(100)$ & 15 & $180 / 180(100)$ \\
\hline \multicolumn{5}{|l|}{ Congenital hypothyroidism } \\
\hline Thyroid-stimulating hormone & 15 & $150 / 150(100)$ & 15 & $150 / 150(100)$ \\
\hline T4, total & 8 & $80 / 80(100)$ & 9 & $81 / 81(100)$ \\
\hline $\mathrm{T} 4$, free & 6 & $42 / 42(100)$ & 5 & $42 / 45(93)$ \\
\hline
\end{tabular}

Abbreviation: T4, thyroxine. 


\section{Journal of LABORATORY MEDICINE and QUALITY ASSURANCE}

Soo-Youn Lee • Quality Assessment of Metabolite Testing

Table 3. Cut-off values used in expanded neonatal screening tests using tandem mass spectrometry in the first trial in 2016

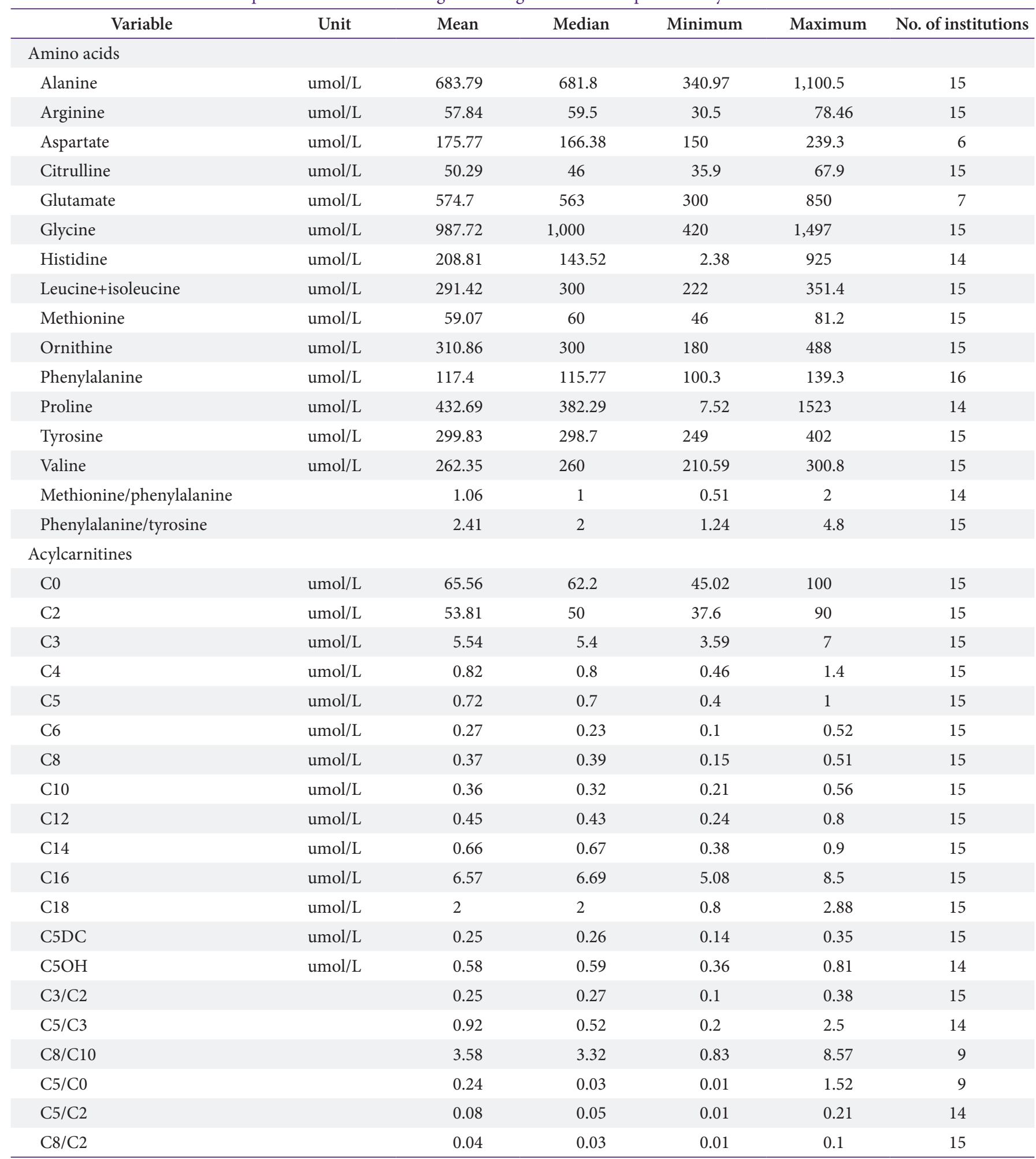


Journal of LABORATORY MEDICINE and QUALITY ASSURANCE

Soo-Youn Lee • Quality Assessment of Metabolite Testing

Table 4. Proficiency testing results for methylmalonic acid and vanillylmandelic acid

\begin{tabular}{|c|c|c|c|c|c|c|c|c|}
\hline Variable & Trial & Specimen no. & No. & $\begin{array}{c}\text { Mean } \pm \text { standard } \\
\text { deviation }\end{array}$ & $\begin{array}{l}\text { Coefficient of } \\
\text { variation }(\%)\end{array}$ & Median & Minimum & Maximum \\
\hline \multicolumn{9}{|c|}{ Methylmalonic acid (mg/L) } \\
\hline \multirow[t]{6}{*}{2016} & 1 st & CMM-16-01 & 4 & $1.28 \pm 0.21$ & 16.17 & 1.30 & 1.00 & 1.50 \\
\hline & & CMM-16-02 & & $5.60 \pm 1.03$ & 18.44 & 5.60 & 4.40 & 6.80 \\
\hline & & CMM-16-03 & & $10.28 \pm 2.15$ & 20.89 & 10.55 & 7.40 & 12.60 \\
\hline & 2nd & CMM-16-04 & 4 & $4.93 \pm 0.96$ & 19.57 & 4.75 & 4.00 & 6.20 \\
\hline & & CMM-16-05 & & $1.13 \pm 0.26$ & 23.38 & 1.05 & 0.90 & 1.50 \\
\hline & & CMM-16-06 & & $7.65 \pm 1.15$ & 15.04 & 7.65 & 6.40 & 8.90 \\
\hline \multirow[t]{6}{*}{2017} & 1 st & CMM-17-01 & 4 & $0.65 \pm 0.06$ & 8.88 & 0.65 & 0.60 & 0.70 \\
\hline & & CMM-17-02 & & $0.65 \pm 0.06$ & 8.88 & 0.65 & 0.60 & 0.70 \\
\hline & & CMM-17-03 & & $0.68 \pm 0.10$ & 14.18 & 0.65 & 0.60 & 0.80 \\
\hline & 2nd & CMM-17-04 & 5 & $5.38 \pm 0.63$ & 11.64 & 5.40 & 4.70 & 6.00 \\
\hline & & CMM-17-05 & & $1.46 \pm 0.11$ & 7.81 & 1.50 & 1.30 & 1.60 \\
\hline & & CMM-17-06 & & $8.32 \pm 0.67$ & 8.08 & 7.90 & 7.70 & 9.10 \\
\hline \multicolumn{9}{|c|}{ Vannillymandelic acid (mg/L) } \\
\hline \multirow[t]{6}{*}{2016} & 1 st & CMV-16-01 & 7 & $29.26 \pm 0.71$ & 2.44 & 29.10 & 28.40 & 30.50 \\
\hline & & CMV-16-02 & & $14.84 \pm 0.56$ & 3.79 & 15.00 & 13.90 & 15.30 \\
\hline & & CMV-16-03 & & $4.64 \pm 0.93$ & 20.08 & 5.00 & 2.80 & 5.40 \\
\hline & 2nd & CMV-16-04 & 7 & $14.91 \pm 1.45$ & 9.70 & 15.40 & 12.00 & 16.60 \\
\hline & & CMV-16-05 & & $28.80 \pm 4.80$ & 16.67 & 27.90 & 22.00 & 38.10 \\
\hline & & CMV-16-06 & & $5.03 \pm 0.28$ & 5.47 & 5.00 & 4.70 & 5.40 \\
\hline \multirow[t]{6}{*}{2017} & $1 \mathrm{st}$ & CMV-17-01 & 7 & $14.67 \pm 1.14$ & 7.76 & 14.60 & 13.30 & 16.10 \\
\hline & & CMV-17-02 & & $26.89 \pm 3.75$ & 13.95 & 25.70 & 23.40 & 34.50 \\
\hline & & CMV-17-03 & & $3.04 \pm 0.16$ & 5.32 & 3.10 & 2.80 & 3.30 \\
\hline & 2nd & CMV-17-04 & 7 & $4.50 \pm 0.22$ & 4.80 & 4.50 & 4.20 & 4.80 \\
\hline & & CMV-17-05 & & $17.37 \pm 1.07$ & 6.16 & 17.80 & 15.80 & 18.50 \\
\hline & & CMV-17-06 & & $2.69 \pm 0.20$ & 7.27 & 2.60 & 2.50 & 3.00 \\
\hline
\end{tabular}

위음성 결과를 보인다면 문제가 될 수 있다.

$\mathrm{MS} / \mathrm{MS}$ 를 이용한 광범위선별검사는 수십 종의 항목을 동 시에 분석하고 관련 성분들과 해당 질환에서의 증감 양상 등을 고려하셔 종합적으로 판정하는 검사이기 때문에 개별 성분의 수치값 자체가 절대적으로 중요한 것은 아니다. 또한 표준화된 검사가 아니라 각 기관에서 사용하는 장비와 시약, 분석조건이 달라 얻어지는 결과수치도 차이를 보일 수 있고, 해당 기관의 검사자료를 기반으로 자체적으로 설정한 판정기준치를 활용 해 이상결과 여부를 판정하게 된다. 2017년도부터는 정도관리 협회 방침에 따라 수치결과에 대한 상세 통계분석결과도 제공 되었는데, 본 신빙도조사에서 수치결과는 최종 판정대상이 아 니며 참고자료로 이용하면 도움이 될 수도 있다. 광범위선별검 사에서도 개별 종목별로 보면 일부 종목에서 판정 불일치가 관
찰되었으며, 이들 기관에서는 자체적으로 기관 내 판정기준치 및 검사방법에 대한 검토 후 필요시 조치할 것이 권장된다. 특 정 종목에서 반복적으로 판정 불일치를 보이는 경우라든가 판 정기준치가 타기관에 비해 유의하게 다른 경우에는 전체 검사 결과에 대한 분포 그래프를 타기관들과 비교하면서 살펴보는 것이 도움이 될 것이다. 신빙도조사에서 나타난 바와 같이 현 재 각 기관들에서 사용 중인 판정기준치 수치는 종목에 따라 2 배 이상 차이를 보이는 경우가 흔하다. 기관 자체적으로 주기 적인 판정기준치 검증을 시행하는 것이 필수적인 사항이며, 본 신빙도조사 결과분석자료를 타기관과의 판정기준치 차이, 검 사결과수치 분포의 차이를 파악하는 데 활용하면 되겠다. 또한 $\mathrm{MS} / \mathrm{MS}$ 검사에서 일부 항목들에 대하여 보고하지 않는 기관 의 경우 자체적인 검토를 통하여 보고항목으로 추가를 검토할 
Journal of LABORATORY MEDICINE and QUALITY ASSURANCE

Soo-Youn Lee $\bullet$ Quality Assessment of Metabolite Testing

Table 5. Proficiency testing results for catecholamines

\begin{tabular}{|c|c|c|c|c|c|c|c|c|c|}
\hline Variable & Year & Trial & Specimen no. & No. & $\begin{array}{c}\text { Mean } \pm \text { standard } \\
\text { deviation }\end{array}$ & $\begin{array}{l}\text { Coefficient of } \\
\text { variation }(\%)\end{array}$ & Median & Minimum & Maximum \\
\hline \multicolumn{10}{|c|}{$\begin{array}{l}\text { Catecholamines, plasma } \\
(\mathrm{pg} / \mathrm{mL})\end{array}$} \\
\hline \multirow[t]{12}{*}{ Dopamine } & 2016 & 1st & CMCP-16-01 & 7 & $800.4 \pm 361.7$ & 45.2 & 709.8 & 465.5 & $1,510.7$ \\
\hline & & & СMCP-16-02 & & $50.3 \pm 34.4$ & 68.3 & 42.5 & 10.0 & 104.8 \\
\hline & & & СMCP-16-03 & & $300.3 \pm 78.9$ & 26.3 & 285.8 & 196.2 & 401.9 \\
\hline & & 2 nd & СMCP-16-04 & 7 & $39.3 \pm 21.1$ & 53.7 & 41.4 & 10.0 & 71.1 \\
\hline & & & СMCP-16-05 & & $273.2 \pm 19.1$ & 7.0 & 273.7 & 251.7 & 305.6 \\
\hline & & & СMCP-16-06 & & $471.4 \pm 67.6$ & 14.3 & 461.9 & 395.7 & 556.8 \\
\hline & 2017 & $1 \mathrm{st}$ & СMCP-17-01 & 6 & $413.1 \pm 67.4$ & 16.3 & 386.4 & 361.6 & 545.6 \\
\hline & & & CMCP-17-02 & & $383.5 \pm 114.9$ & 30.0 & 426.1 & 156.7 & 456.7 \\
\hline & & & СMCP-17-03 & & $74.9 \pm 18.6$ & 24.9 & 68.4 & 62.7 & 111.1 \\
\hline & & 2nd & СMCP-17-04 & 6 & $92.3 \pm 12.6$ & 13.6 & 92.5 & 73.0 & 110.6 \\
\hline & & & СMCP-17-05 & & $445.5 \pm 110.8$ & 24.9 & 402.7 & 334.4 & 620.8 \\
\hline & & & СMCP-17-06 & & $433.7 \pm 130.7$ & 30.1 & 453.7 & 209.0 & 609.8 \\
\hline \multirow[t]{12}{*}{ Epinephrine } & 2016 & $1 \mathrm{st}$ & CMCP-16-01 & 7 & $400.3 \pm 68.9$ & 17.2 & 423.7 & 261.7 & 475.7 \\
\hline & & & СMCP-16-02 & & $42.0 \pm 14.5$ & 34.6 & 43.6 & 22.7 & 66.1 \\
\hline & & & СМСР-16-03 & & $181.9 \pm 12.4$ & 6.8 & 185.3 & 158.1 & 197.1 \\
\hline & & 2nd & СМСР-16-04 & 7 & $49.7 \pm 14.4$ & 28.9 & 51.6 & 27.8 & 63.8 \\
\hline & & & CMCP-16-05 & & $232.5 \pm 33.7$ & 14.5 & 228.2 & 195.0 & 280.8 \\
\hline & & & СMCP-16-06 & & $289.9 \pm 46.1$ & 15.9 & 298.6 & 232.5 & 362.5 \\
\hline & 2017 & 1st & СMCР-17-01 & 7 & $1116.5 \pm 99.5$ & 8.9 & $1,145.9$ & 923.1 & $1,211.6$ \\
\hline & & & СMCP-17-02 & & $291.2 \pm 90.7$ & 31.2 & 272.5 & 201.8 & 485.8 \\
\hline & & & СMCP-17-03 & & $73.8 \pm 12.7$ & 17.2 & 72.6 & 58.2 & 92.6 \\
\hline & & 2nd & CMCP-17-04 & 7 & $56.3 \pm 8.1$ & 14.5 & 59.4 & 42.2 & 66.2 \\
\hline & & & СMCP-17-05 & & $1088.4 \pm 122.9$ & 11.3 & $1,073.2$ & 954.7 & $1,238.9$ \\
\hline & & & СMCP-17-06 & & $314.3 \pm 117.3$ & 37.3 & 272.9 & 238.2 & 550.0 \\
\hline \multirow[t]{12}{*}{ Norepinephrine } & 2016 & 1st & CMCP-16-01 & 7 & $1772.7 \pm 392.0$ & 22.1 & $1,637.0$ & $1,325.8$ & $2,570.4$ \\
\hline & & & СMCP-16-02 & & $142.3 \pm 7.7$ & 5.4 & 145.8 & 127.4 & 149.5 \\
\hline & & & CMCP-16-03 & & $754.8 \pm 141.9$ & 18.8 & 744.7 & 586.6 & $1,021.4$ \\
\hline & & 2nd & СMCP-16-04 & 7 & $179.5 \pm 50.0$ & 27.8 & 168.6 & 133.0 & 265.9 \\
\hline & & & СMCP-16-05 & & $898.3 \pm 147.8$ & 16.5 & 940.2 & 696.0 & $1,087.5$ \\
\hline & & & CMCP-16-06 & & $1086.4 \pm 141.5$ & 13.0 & $1,106.4$ & 904.3 & $1,319.3$ \\
\hline & 2017 & 1st & СMCP-17-01 & 7 & $1279.0 \pm 52.4$ & 4.1 & $1,271.0$ & $1,201.7$ & $1,347.1$ \\
\hline & & & СMCP-17-02 & & $962.6 \pm 190.8$ & 19.8 & $1,068.7$ & 616.7 & $1,109.8$ \\
\hline & & & СMCP-17-03 & & $267.3 \pm 23.8$ & 8.9 & 269.9 & 229.4 & 307.7 \\
\hline & & 2nd & CMCP-17-04 & 7 & $230.8 \pm 24.1$ & 10.4 & 224.9 & 193.6 & 263.0 \\
\hline & & & СMCP-17-05 & & $1272.4 \pm 82.2$ & 6.5 & $1,265.1$ & $1,167.2$ & $1,395.7$ \\
\hline & & & CMCP-17-06 & & $1040.8 \pm 53.0$ & 5.1 & $1,054.6$ & 944.0 & $1,097.2$ \\
\hline
\end{tabular}

(Continued to the next page) 
Journal of LABORATORY MEDICINE and QUALITY ASSURANCE

Soo-Youn Lee $\bullet$ Quality Assessment of Metabolite Testing

Table 5. Continued

\begin{tabular}{|c|c|c|c|c|c|c|c|c|c|}
\hline Variable & Year & Trial & Specimen no. & No. & $\begin{array}{l}\text { Mean } \pm \text { standard } \\
\text { deviation }\end{array}$ & $\begin{array}{l}\text { Coefficient of } \\
\text { variation }(\%)\end{array}$ & Median & Minimum & Maximum \\
\hline \multicolumn{10}{|c|}{$\begin{array}{l}\text { Catecholamines, urine } \\
(\mathrm{ng} / \mathrm{mL})\end{array}$} \\
\hline \multirow[t]{12}{*}{ Dopamine } & 2016 & $1 \mathrm{st}$ & CMU-16-01 & 7 & $502.7 \pm 28.4$ & 5.6 & 492.4 & 469.3 & 548.5 \\
\hline & & & CMU-16-02 & & $93.6 \pm 8.0$ & 8.5 & 90.7 & 85.4 & 108.5 \\
\hline & & & CMU-16-03 & & $504.0 \pm 37.5$ & 7.4 & 483.8 & 463.9 & 563.1 \\
\hline & & 2nd & CMU-16-04 & 7 & $86.1 \pm 11.0$ & 12.8 & 87.6 & 69.5 & 105.0 \\
\hline & & & CMU-16-05 & & $490.7 \pm 33.5$ & 6.8 & 498.8 & 447.0 & 540.5 \\
\hline & & & CMU-16-06 & & $493.4 \pm 36.4$ & 7.4 & 504.1 & 445.2 & 547.6 \\
\hline & 2017 & $1 \mathrm{st}$ & CMU-17-01 & 7 & $123.3 \pm 18.4$ & 14.9 & 128.8 & 91.5 & 141.4 \\
\hline & & & CMU-17-02 & & $501.3 \pm 56.1$ & 11.2 & 494.5 & 416.0 & 575.2 \\
\hline & & & CMU-17-03 & & $348.2 \pm 38.4$ & 11.0 & 348.6 & 283.3 & 391.3 \\
\hline & & 2nd & CMU-17-04 & 7 & $460.6 \pm 32.1$ & 7.0 & 454.0 & 427.0 & 512.6 \\
\hline & & & CMU-17-05 & & $483.5 \pm 48.8$ & 10.1 & 476.9 & 396.3 & 549.7 \\
\hline & & & CMU-17-06 & & $87.2 \pm 7.7$ & 8.9 & 88.6 & 75.4 & 100.3 \\
\hline \multirow[t]{12}{*}{ Epinephrine } & 2016 & $1 \mathrm{st}$ & CMU-16-01 & 7 & $88.1 \pm 8.9$ & 10.1 & 88.9 & 74.9 & 100.8 \\
\hline & & & CMU-16-02 & & $14.0 \pm 1.9$ & 13.9 & 13.9 & 11.7 & 17.4 \\
\hline & & & CMU-16-03 & & $85.5 \pm 6.6$ & 7.7 & 86.1 & 74.0 & 92.1 \\
\hline & & 2nd & CMU-16-04 & 7 & $15.8 \pm 2.6$ & 16.2 & 14.7 & 13.7 & 20.9 \\
\hline & & & CMU-16-05 & & $91.0 \pm 17.1$ & 18.8 & 86.2 & 68.8 & 123.9 \\
\hline & & & CMU-16-06 & & $90.8 \pm 14.2$ & 15.6 & 87.1 & 70.9 & 116.2 \\
\hline & 2017 & $1 \mathrm{st}$ & CMU-17-01 & 7 & $12.6 \pm 2.9$ & 23.5 & 11.9 & 8.7 & 15.8 \\
\hline & & & CMU-17-02 & & $83.8 \pm 13.3$ & 15.9 & 86.6 & 64.8 & 101.0 \\
\hline & & & CMU-17-03 & & $62.0 \pm 9.9$ & 16.0 & 65.6 & 49.1 & 75.4 \\
\hline & & 2nd & CMU-17-04 & 7 & $87.3 \pm 13.9$ & 15.9 & 84.4 & 74.4 & 116.3 \\
\hline & & & CMU-17-05 & & $85.6 \pm 17.5$ & 20.4 & 83.7 & 61.9 & 120.3 \\
\hline & & & CMU-17-06 & & $14.6 \pm 1.9$ & 13.0 & 14.9 & 10.9 & 17.0 \\
\hline \multirow[t]{12}{*}{ Norepinephrine } & 2016 & 1 st & CMU-16-01 & 7 & $201.2 \pm 8.0$ & 4.0 & 198.8 & 188.4 & 213.1 \\
\hline & & & CMU-16-02 & & $46.1 \pm 1.4$ & 2.9 & 46.4 & 43.4 & 47.4 \\
\hline & & & CMU-16-03 & & $202.0 \pm 12.3$ & 6.1 & 201.4 & 179.5 & 215.6 \\
\hline & & 2nd & CMU-16-04 & 7 & $46.9 \pm 2.9$ & 6.2 & 46.0 & 44.1 & 51.9 \\
\hline & & & CMU-16-05 & & $200.4 \pm 6.1$ & 3.1 & 198.7 & 193.4 & 212.1 \\
\hline & & & CMU-16-06 & & $202.0 \pm 10.1$ & 5.0 & 197.7 & 194.3 & 222.3 \\
\hline & 2017 & $1 \mathrm{st}$ & CMU-17-01 & 7 & $43.8 \pm 4.5$ & 10.2 & 44.4 & 37.0 & 49.9 \\
\hline & & & CMU-17-02 & & $191.0 \pm 16.6$ & 8.7 & 199.6 & 162.1 & 206.3 \\
\hline & & & CMU-17-03 & & $180.4 \pm 14.6$ & 8.1 & 187.5 & 159.1 & 195.3 \\
\hline & & 2nd & CMU-17-04 & 7 & $182.3 \pm 14.6$ & 8.0 & 180.6 & 163.4 & 207.3 \\
\hline & & & CMU-17-05 & & $189.4 \pm 14.3$ & 7.6 & 186.7 & 169.4 & 212.3 \\
\hline & & & CMU-17-06 & & $47.3 \pm 2.4$ & 5.1 & 46.4 & 44.8 & c \\
\hline
\end{tabular}


Journal of LABORATORY MEDICINE and QUALITY ASSURANCE

Soo-Youn Lee $\bullet$ Quality Assessment of Metabolite Testing

Table 6. Proficiency testing results for metanephrines

\begin{tabular}{|c|c|c|c|c|c|c|c|c|c|}
\hline Variable & Year & Trial & Specimen no. & No. & $\begin{array}{c}\text { Mean } \pm \text { standard } \\
\text { deviation }\end{array}$ & $\begin{array}{l}\text { Coefficient of } \\
\text { variation }(\%)\end{array}$ & Median & Minimum & Maximum \\
\hline \multicolumn{10}{|l|}{$\begin{array}{l}\text { Metanephrines, plasma } \\
(\mathrm{nmol} / \mathrm{L})\end{array}$} \\
\hline \multirow[t]{12}{*}{ Metanephrine } & 2016 & $1 \mathrm{st}$ & CMMP-16-01 & 5 & $3.98 \pm 0.24$ & 6.08 & 3.90 & 3.80 & 4.40 \\
\hline & & & CMMP-16-02 & & $0.40 \pm 0.17$ & 42.21 & 0.32 & 0.30 & 0.70 \\
\hline & & & CMMP-16-03 & & $3.71 \pm 0.34$ & 9.10 & 3.63 & 3.30 & 4.10 \\
\hline & & $2 \mathrm{nd}$ & CMMP-16-04 & 5 & $0.48 \pm 0.85$ & 177.02 & 0.10 & 0.10 & 2.00 \\
\hline & & & CMMP-16-05 & & $6.18 \pm 0.77$ & 12.50 & 6.00 & 5.50 & 7.50 \\
\hline & & & CMMP-16-06 & & $4.42 \pm 1.13$ & 25.57 & 3.90 & 3.70 & 6.40 \\
\hline & 2017 & 1st & CMMP-17-01 & 5 & $4.05 \pm 0.28$ & 6.88 & 3.95 & 3.72 & 4.49 \\
\hline & & & CMMP-17-02 & & $0.53 \pm 0.29$ & 55.03 & 0.43 & 0.29 & 1.10 \\
\hline & & & CMMP-17-03 & & $0.82 \pm 0.14$ & 17.60 & 0.77 & 0.70 & 1.09 \\
\hline & & 2nd & CMMP-17-04 & 5 & $7.51 \pm 0.50$ & 6.66 & 7.30 & 6.97 & 8.26 \\
\hline & & & CMMP-17-05 & & $3.73 \pm 0.36$ & 9.66 & 3.59 & 3.36 & 4.30 \\
\hline & & & CMMP-17-06 & & $0.22 \pm 0.13$ & 58.29 & 0.21 & 0.09 & 0.47 \\
\hline \multirow[t]{12}{*}{ Normaetanephrine } & 2016 & 1st & CMMP-16-01 & 5 & $2.79 \pm 0.21$ & 7.35 & 2.80 & 2.60 & 3.10 \\
\hline & & & CMMP-16-02 & & $0.88 \pm 0.61$ & 68.77 & 1.00 & 0.28 & 1.72 \\
\hline & & & CMMP-16-03 & & $2.52 \pm 0.23$ & 8.94 & 2.59 & 2.21 & 2.80 \\
\hline & & 2nd & CMMP-16-04 & 5 & $0.80 \pm 1.32$ & 157.20 & 0.30 & 0.20 & 3.20 \\
\hline & & & CMMP-16-05 & & $34.70 \pm 3.52$ & 10.10 & 34.20 & 30.20 & 39.90 \\
\hline & & & CMMP-16-06 & & $9.60 \pm 2.15$ & 22.50 & 8.60 & 8.40 & 13.40 \\
\hline & 2017 & 1st & CMMP-17-01 & 5 & $19.33 \pm 1.12$ & 5.78 & 19.24 & 18.20 & 21.18 \\
\hline & & & CMMP-17-02 & & $1.22 \pm 0.66$ & 54.23 & 1.00 & 0.51 & 2.03 \\
\hline & & & CMMP-17-03 & & $4.12 \pm 0.42$ & 10.17 & 3.96 & 3.75 & 4.91 \\
\hline & & 2nd & CMMP-17-04 & 5 & $38.57 \pm 4.68$ & 12.13 & 38.88 & 30.92 & 43.95 \\
\hline & & & CMMP-17-05 & & $19.60 \pm 2.59$ & 13.24 & 19.66 & 15.27 & 23.23 \\
\hline & & & CMMP-17-06 & & $0.64 \pm 0.37$ & 57.81 & 0.70 & 0.23 & 1.02 \\
\hline \multicolumn{10}{|l|}{$\begin{array}{l}\text { Metanephrines, urine } \\
(\mathrm{ng} / \mathrm{mL})\end{array}$} \\
\hline \multirow[t]{12}{*}{ Metanephrine } & 2016 & $1 \mathrm{st}$ & CMU-16-01 & 7 & $543.6 \pm 49.0$ & 9.0 & 548.0 & 488.4 & 615.1 \\
\hline & & & CMU-16-02 & & $102.1 \pm 10.2$ & 10.0 & 103.0 & 83.5 & 116.4 \\
\hline & & & CMU-16-03 & & $540.6 \pm 25.4$ & 4.7 & 533.2 & 510.3 & 585.0 \\
\hline & & 2nd & CMU-16-04 & 7 & $102.9 \pm 9.9$ & 9.6 & 102.0 & 90.8 & 121.3 \\
\hline & & & CMU-16-05 & & $521.0 \pm 53.5$ & 10.3 & 530.2 & 442.8 & 590.5 \\
\hline & & & CMU-16-06 & & $528.5 \pm 47.8$ & 9.0 & 535.0 & 432.9 & 589.6 \\
\hline & 2017 & $1 s t$ & CMU-17-01 & 6 & $95.4 \pm 20.1$ & 21.1 & 87.8 & 70.7 & 133.8 \\
\hline & & & CMU-17-02 & & $558.9 \pm 42.4$ & 7.6 & 553.4 & 512.8 & 617.0 \\
\hline & & & CMU-17-03 & & $542.1 \pm 79.8$ & 14.7 & 571.9 & 410.3 & 630.9 \\
\hline & & 2nd & CMU-17-04 & 6 & $520.3 \pm 55.5$ & 10.7 & 514.9 & 438.8 & 614.0 \\
\hline & & & CMU-17-05 & & $525.5 \pm 47.9$ & 9.1 & 515.4 & 455.6 & 604.1 \\
\hline & & & CMU-17-06 & & $104.1 \pm 10.4$ & 10.0 & 101.1 & 93.0 & 124.4 \\
\hline
\end{tabular}

(Continued to the next page) 
Journal of LABORATORY MEDICINE and QUALITY ASSURANCE

Soo-Youn Lee • Quality Assessment of Metabolite Testing

Table 6. Continued

\begin{tabular}{|c|c|c|c|c|c|c|c|c|c|}
\hline Variable & Year & Trial & Specimen no. & No. & $\begin{array}{c}\text { Mean } \pm \text { standard } \\
\text { deviation }\end{array}$ & $\begin{array}{l}\text { Coefficient of } \\
\text { variation }(\%)\end{array}$ & Median & Minimum & Maximum \\
\hline \multirow[t]{12}{*}{ Normaetanephrine } & 2016 & $1 \mathrm{st}$ & CMU-16-01 & 7 & $1376.6 \pm 80.3$ & 5.8 & $1,370.0$ & $1,244.7$ & $1,455.4$ \\
\hline & & & CMU-16-02 & & $334.5 \pm 17.0$ & 5.1 & 335.0 & 302.5 & 351.5 \\
\hline & & & CMU-16-03 & & $1380.3 \pm 78.5$ & 5.7 & $1,382.5$ & $1,232.5$ & $1,472.2$ \\
\hline & & 2nd & CMU-16-04 & 7 & $319.8 \pm 25.9$ & 8.1 & 327.1 & 281.7 & 346.1 \\
\hline & & & CMU-16-05 & & $1372.7 \pm 116.4$ & 8.5 & $1,402.8$ & $1,141.0$ & $1,499.7$ \\
\hline & & & CMU-16-06 & & $1360.0 \pm 78.7$ & 5.8 & $1,390.0$ & $1,222.0$ & $1,470.2$ \\
\hline & 2017 & 1 st & CMU-17-01 & 6 & $250.1 \pm 36.0$ & 14.4 & 251.8 & 208.4 & 317.6 \\
\hline & & & CMU-17-02 & & $1392.8 \pm 38.4$ & 2.8 & $1,380.6$ & $1,337.9$ & $1,442.7$ \\
\hline & & & CMU-17-03 & & $1043.0 \pm 49.3$ & 4.7 & $1,054.2$ & 959.4 & $1,100.8$ \\
\hline & & 2nd & CMU-17-04 & 6 & $1222.4 \pm 107.3$ & 8.8 & $1,181.5$ & $1,107.0$ & $1,393.9$ \\
\hline & & & CMU-17-05 & & $1334.5 \pm 79.7$ & 6.0 & $1,326.2$ & $1,229.0$ & $1,475.0$ \\
\hline & & & CMU-17-06 & & $328.9 \pm 30.0$ & 9.1 & 322.7 & 290.0 & 389.2 \\
\hline
\end{tabular}

Table 7. Proficiency testing results for amino acid analysis (unit, $\mu \mathrm{mol} / \mathrm{L}$ )

\begin{tabular}{|c|c|c|c|c|c|c|c|c|c|c|}
\hline Year & Trial & $\begin{array}{c}\text { Specimen } \\
\text { no. }\end{array}$ & Intended response & Reported respons & No. & $\begin{array}{c}\text { Reported } \\
\text { components }\end{array}$ & No. & Median & Minimum & Maximum \\
\hline \multirow[t]{7}{*}{2016} & $1 s t$ & CMA-16-01 & Homocystinuria & Homocystinuria & 5 & Methionine & 5 & 1,215 & 890.2 & 1,520 \\
\hline & & & & & & Homocystine & 4 & 158.7 & 110 & 253 \\
\hline & & CMA-16-02 & Hyperornithinemia & Hyperornithinemia & 3 & Ornithine & 5 & 1,481 & 767 & 1,629 \\
\hline & & & & HHH syndrome & 2 & & & & & \\
\hline & 2 nd & CMA-16-03 & Hyperlysinemia & Hyperlysinemia & 5 & Lysine & 5 & 2,095 & 918.5 & 2,210 \\
\hline & & CMA-16-04 & Hyerglycinemia & Hyerglycinemia & 5 & Glycine & 5 & 2,162 & $1,221.2$ & 2,478 \\
\hline & & & & & & Alanine & 4 & 719.7 & 574.3 & 744 \\
\hline \multirow[t]{9}{*}{2017} & 1 st & CMA-17-01 & MSUD & MSUD & 4 & allo-isoleucine & 4 & 794 & 712 & 887 \\
\hline & & & & No abnormality & 1 & Isoleucine & 5 & 476 & 58 & 1,154 \\
\hline & & & & & & Leucine & 5 & 489 & 125 & 527 \\
\hline & & & & & & Valine & 5 & 1,026 & 157 & 1,191 \\
\hline & & CMA-17-02 & No abnormality & No abnormality & 4 & & & & & \\
\hline & & & & MSUD & 1 & & & & & \\
\hline & 2nd & CMA-17-03 & Tyrosinemia type I & Tyrosinemia type I & 5 & Methionine & 6 & 304 & 267 & 370 \\
\hline & & & & Hypermethioninemia & 1 & Tyrosine & 6 & 385 & 323 & 416 \\
\hline & & CMA-17-04 & No abnormality & No abnormality & 6 & & & & & \\
\hline
\end{tabular}

Abbreviations: $\mathrm{HHH}$, hyperornithinemia-hyperammonemia-homocitrullinuria; MSUD, maple syrup urine disease.

것이 권장된다. 관련 성분의 상대적 비율을 관찰하면 진단의 정확성을 향상시키는 데 도움이 되며, 신빙도조사 결과에 따르 면 phenylalanine/tyrosine과 $\mathrm{C} 3 / \mathrm{C} 2$ 비율 등 주요 항목은 현 재 모든 기관에서 적용하고 있는 것으로 나타났다.

유기산검사는 각 회차별 2검체씩을 발송해 오다가 2017
년 2차 시기부터 3검체씩으로 증가시켰으며, 질환명과 판정 기준치 이상의 증가를 보이는 유기산들을 보고하도록 하였 다. Malonic academia, glutaric aciduria, PKU와 같은 전형 적인 증감 양상을 보이는 검체와 정상인 검체, 그리고 lactic acidosis, ketosis를 시사하는 비특이적 소견의 검체도 포함되 


\section{Journal of LABORATORY MEDICINE and QUALITY ASSURANCE}

\section{Soo-Youn Lee • Quality Assessment of Metabolite Testing}

Table 8. Proficiency testing results for organic acid analysis (unit, $\mathrm{mmol} / \mathrm{mol}$ creatinine)

\begin{tabular}{|c|c|c|c|c|c|c|c|c|c|c|}
\hline Year & Trial & $\begin{array}{l}\text { Specimen } \\
\text { no. }\end{array}$ & $\begin{array}{l}\text { Intended } \\
\text { response }\end{array}$ & Reported respons & No. & Reported components & No. & Median & Minimum & Maximum \\
\hline \multirow[t]{6}{*}{2016} & 1 st & CMO-16-01 & Malonic acidemia & Malonic acidemia & 3 & Malonic acid & 3 & 284.4 & 189.6 & 328.1 \\
\hline & & CMO-16-02 & $\begin{array}{l}\text { Glutaric aciduria } \\
\text { (type } 2)\end{array}$ & $\begin{array}{l}\text { Glutaric aciduria } \\
\text { (type } 2)\end{array}$ & 3 & Glutaric acid & 3 & 218.3 & 198.6 & 287.2 \\
\hline & & & & & & Ethylmalonic acid & 3 & 93 & 79.7 & 138.9 \\
\hline & 2nd & CMO-16-03 & Hyperoxaluria & Hyperoxaluria & 2 & Glycolic acid & 2 & & 178.1 & 179.5 \\
\hline & & & & & & Oxalic acid & 2 & & 97.9 & 108.2 \\
\hline & & CMO-16-04 & $\begin{array}{l}\text { No abnormality } \\
\text { detected }\end{array}$ & $\begin{array}{l}\text { No abnormality } \\
\text { detected }\end{array}$ & 2 & & & & & \\
\hline \multirow[t]{14}{*}{2017} & 1 st & CMO-17-01 & Phenylketonuria & Phenylketonuria & 3 & Phenyllactic acid & 3 & 474.9 & 403.8 & 748.3 \\
\hline & & & & & & Phenylpyruvic acid & 2 & & 50 & 91.1 \\
\hline & & & & & & 4-hydroxyphenyllactic acid & 3 & 482.7 & 498.1 & 839.2 \\
\hline & & CMO-17-02 & $\begin{array}{l}\text { No abnormality } \\
\text { detected }\end{array}$ & $\begin{array}{l}\text { No abnormality } \\
\text { detected }\end{array}$ & 3 & & & & & \\
\hline & & CMO-17-03 & $\begin{array}{l}\text { Lactic acidemia/ } \\
\text { ketosis }\end{array}$ & Lactic acidemia & 2 & Lactate & 3 & 61.3 & 52.2 & 106.7 \\
\hline & & & & Ketosis & 1 & 4-hydroxyphenyllactic acid & 2 & & 74.5 & 84.7 \\
\hline & & & & & & 2-hydroxybutyric acid & 3 & 28.5 & 27.6 & 28.8 \\
\hline & & & & & & 3-hydroxybutyric acid & 3 & 118.9 & 114.5 & 232.6 \\
\hline & & & & & & 2-hydroxyisobutyric acid & 1 & 42.2 & & \\
\hline & 2nd & CMO-17-04 & $\begin{array}{l}\text { No abnormality } \\
\text { detected }\end{array}$ & $\begin{array}{l}\text { No abnormality } \\
\text { detected }\end{array}$ & 4 & & & & & \\
\hline & & CMO-17-05 & $\begin{array}{l}\mathrm{N} \text {-Acetylaspartic } \\
\text { aciduria }\end{array}$ & $\begin{array}{l}\text { N-Acetylaspartic } \\
\text { aciduria }\end{array}$ & 4 & $\mathrm{~N}$-acetylaspartic acid & 4 & 448.4 & 178.1 & $1,554.6$ \\
\hline & & CMO-17-06 & $\begin{array}{l}\text { Short chain } \\
\text { acyl-CoA } \\
\text { dehydrogenase } \\
\text { deficiency }\end{array}$ & $\begin{array}{l}\text { Short chain } \\
\text { acyl-CoA } \\
\text { dehydrogenase } \\
\text { deficiency }\end{array}$ & 4 & Ethylmalonic acid & 4 & 241.2 & 148.1 & 409.2 \\
\hline & & & & & & Methylsuccinic acid & 4 & 46.4 & 40.2 & 64.4 \\
\hline & & & & & & 3-hydroxybutyric acid & 4 & 81.1 & 55.7 & 99.4 \\
\hline
\end{tabular}

었다. 원래 검체 제조 시 의도한 질환명을 정답으로 간주하였 는데, 모든 기관에서 합당한 질환명을 제시하였다. 하지만, 해 당 검출 물질에 대한 상승 정도는 기관별로 상당한 차이를 보 였고 증가한 것으로 보고한 성분이 다소 차이를 보이는 경우 도 있었다. 다만, 제조 시 양성으로 의도한 성분이 검출되지 않 거나 다른 농도를 보인 경우도 있는데, 검체운송이나 취급상의 문제일 가능성을 배제할 수 없다.

아미노산검사는 회차별 2개 검체를 발송하였다. 예년 신빙 도조사에서는 각 기관이 제출한 측정값을 제시하는 것으로 평 가를 대신해왔었는데 이번 신빙도조사에서는 최종 결과해석 을 중심으로 판정하였다. 유기산검사와 마찬가지로 원래 검체
제조 시 의도한 질환명을 정답으로 간주하였는데, 해당 대사이 상질환에 대한 전형적인 양상을 보이는 검체에 대해서는 대부 분의 기관에서 보고한 진단명이 일치하였으나 일부 검체에 대 해 다른 질환명을 제출한 기관이 있었고 검체바뀜 또는 결과입 력 오류가 의심되는 사례도 나타났다. 양성으로 보고한 아미노 산 성분들의 수치결과를 보면, 역시 그 상승 정도는 기관별로 차이를 보였으며, 검사법의 차이 또는 검체 운송이나 보관상의 문제가 원인일 가능성도 있겠다.

$\mathrm{MMA}, \mathrm{VMA}$ 항목의 경우 2017년도 2차 시까지 각각 5기 관, 7 기관이 참여하였다. 다른 종목들에 비하면 coefficient of variation $(\mathrm{CV}) 25 \%$ 이내로 모든 기관에서 비교적 유사한 측 


\section{Journal of LABORATORY MEDICINE and QUALITY ASSURANCE}

Soo-Youn Lee • Quality Assessment of Metabolite Testing

정결과값을 보고하였다. 요중 카테콜라민은 저농도의 검체 1 개를 제외하고는 CV $20 \%$ 이내였다. 요중 메타네프린 항목에 대해서는 총 7 개 기관에서 신빙도조사에 참여하였으며, 응답 한 모든 기관에서 유사한 측정결과값을 보고하여 CV 20\%였 다. 단, 실제 임상검사에서는 카테콜라민과 메타네프린이 무작 위뇨가 아닌 24시간 요를 대상으로 하기 때문에 요수집의 적 정성이 검사결과에 영향을 미치는 다른 변수가 될 것이고, 본 신빙도조사에서는 최종보고 결과와 참고치는 비교해 볼 수는 없는 한계점이 있다. 혈중 메타네프린은 전체적으로 기관별 보 고결과 수치에 상당한 차이가 있으며 CV $100 \%$ 이상을 보인 경우도 있었는데, 검사대상인 혈중농도 자체가 낮은 범위에 있 고 검사가 표준화되지 않았으며, 검체안정성의 문제도 배제할 수없다.

선천성대사이상질환 조기진단을 위한 신생아선별검사는 검 사수치뿐 아니라 결과에 대한 정상 및 비정상에 대한 적절한 판독이 매우 중요하다. 그러나 각 기관에서 검사에 사용하는 시약과 검사방법이 다양하고 정상 및 비정상을 평가할 기준치 가 서로 다른 경우가 많았다. 또한 본 신빙도조사에서 겪는 애 로사항으로 동일검사법 이용기관의 수가 적은 경우 비교 불가 한 점, 다양한 질환 양성 검체를 대량 확보하기 어려운 점, 단 일 성분만이 아닌 다수의 증감 양상이 조합된 검체를 준비해 야 하는 점 등이 있었다. 아미노산이나 유기산은 대사이상질환 의 확진에 중요하므로 주요 성분의 검출과 적절한 결과해석이 이루어지도록 검사를 시행하는 소수의 기관에서는 각별한 주 의를 기울여야 하겠다. 특수대사산물의 경우 최근 검사에 대한 관심과 요구도가 높아지고 있으며 앞으로 시행기관이 더 늘어 날 것으로 전망해본다.

각 기관에서는 신빙도조사결과를 자체적으로도 면밀히 검토 분석하여 분석법의 신뢰성을 확인하고 내부정도관리를 강화 함과 동시에 주기적으로 기준치를 검증하고 결과보고종목 및 결과해석의 차이도 점검해보는 것이 매우 중요할 것으로 생각 된다. 앞으로도 종목 확대, 적절한 정도관리물질의 확보, 관련 인력교육을 포함하여 지속적으로 신빙도조사 프로그램을 개 선 · 발전시킬 수 있는 방향을 모색한다면 검사의 질 향상에 기 여할 수 있을 것으로 생각된다.

\section{감사의 글}

정도관리물질 제조관리와 결과자료정리 등 본 신빙도조사를 위해 수고해주신 삼성서울병원 진단검사의학과 특수화학검사 실 지옥자 선생님들 비롯한 직원 여러분들과 임상강사 선생님 께 감사드린다.

\section{REFERENCES}

1. Song J, Kwon KC, Kim JH, Kim JW, Min WK, Lee SY, et al. Annual report on external quality assessment in metabolic disorders in Korea (2007). J Lab Med Qual Assur 2008;30:151-66.

2. Lee SY, Kwon KC, Kim JH, Kim JW, Park BT, Park HD, et al. Annual report on external quality assessment in biochemical genetics in Korea (2011). J Lab Med Qual Assur 2012;34:S25-49.

3. Lee SY, Kwon KC, Kim JH, Kim JW, Park BT, Park HD, et al. Annual report on external quality assessment in biochemical genetics in Korea (2012). J Lab Med Qual Assur 2013;35:S29-63.

4. Lee SY; Biochemical Genetics Subcommittee, The Korean Association of Quality Assurance for Clinical Laboratory. Annual report on external quality assessment of biochemical genetics in Korea (2013). J Lab Med Qual Assur 2014;36:64-70.

5. Lee SY, Ji OJ, Kwon GC, Kim JW, Park HD, Song J, et al. Annual report on the external quality assessment scheme for biochemical genetics in Korea (2014). J Lab Med Qual Assur 2015;37:56-63.

6. Lee SY, Ji OJ, Kwon GC, Kim JW, Park HD, Song J, et al. Annual report on the external quality assessment scheme for biochemical genetics in Korea (2015). J Lab Med Qual Assur 2016;38:68-76. 
Journal of LABORATORY MEDICINE and QUALITY ASSURANCE

Soo-Youn Lee • Quality Assessment of Metabolite Testing

대사물질검사 신빙도조사 결과보고(2016-2017) 이수연

성균관대학교 의과대학 삼성서울병원 진단검사의학과

2016년도 및 2017년도 신생아선별검사 및 특수대사산물검사에 대한 신빙도조사사업은 연간 총 2 회 시행되었다. 각 회차별로 페닐케톤뇨증, 갈락토오스혈증, 선천성 부신형성과다증, 단풍당뇨증, 호모시스틴뇨증, 선천성 갑상선기능저하증을 포함하는 선천성대사질환 기본 선별검사와 탠덤질량 분석기를 이용한 광범위선별검사를 위한 총 44 개의 건조혈액여과지 검체를 16 기관에 발송하였다. 회신율은 $100 \%$ 로, 타 기관으로 위탁을 보내는 검사항목은 제외하고 각 기관에서 실제로 시행하고 있는 검사들은 모두 참가하였다. 판정기준치에 인접한 값을 보이는 검체들이 포함되어 결과판정 일

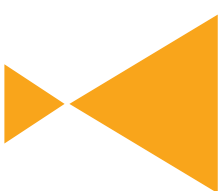

Journal of

LABORATORY MEDICINE and

QUALITY ASSURANCE

치율이 낮아 판정 보류를 한 경우들이 있었다. 타 기관과 차이 나는 측정값 또는 판정을 보이는 경 우에는 기관별 측정값, 측정방법, 판정기준치의 차이와 그에 따른 판정결과의 차이나 결과해석방법 등에 대해 각 기관별로 면밀한 자체 검토가 필요할 것으로 판단되었다. 이외 메틸말론산과 바닐만 델산, 유기산, 아미노산, 카테콜라민 및 메타네프린 항목에 대한 신빙도조사도 시행되었으며 대부분 만족스러운 결과를 보였다. 외부정도관리 프로그램과 지속적인 교육을 통하여 검사의 질을 향상시 킬 수 있을 것으로 기대된다.

(J Lab Med Qual Assur 2018;40:136-148)

교신저자: 이수연

우)06351 서울시 강남구 일원로 81, 성균관대학교 의과대학 삼성서울병원 진단검사의학과

Tel: 02)3410-1834, Fax: 02)3410-2719, E-mail: suddenbz@skku.edu 